\title{
Applicability of Engineered Wetland Systems for Wastewater Treatment in Tanzania - A Review
}

\author{
Stephen E. Mbuligwe, Mengiseny E. Kaseva* and Gabriel R. Kassenga
}

School of Environmental Science and Technology, Ardhi University (ARU), P. O. Box 35176, Dar es Salaam, Tanzania

\begin{abstract}
In the literature on treatment wetlands, a technology that is fast gaining popularity in Tanzania as well as elsewhere in the world, there are misconceptions and missing background links which do not auger well for the development and dissemination of the technology. The misconceptions and missing links pertain to the background, types and classification, treatment mechanisms, and applicability of the technology. These deficiencies constitute the premise of this paper. The paper outlines the background of engineered wetland systems (EWSs) starting with natural treatment systems as a whole, expounding on the reversible transformations between wetlands and aquatic as well as land treatment systems. It particularly dwells on the background, classification, components, functions, treatment mechanisms, and performance as well as applicability of EWSs. Notably, the paper encompasses a discussion on mechanisms that affect pollutants removal in non - conventional EWSs like those employed in environmental remediation of contaminated sites. The paper also profiles treatment performance efficiency data for some existing EWSs. Furthermore, it discusses the applicability of the technology in Tanzania.
\end{abstract}

Keywords: Engineered wetland systems (EWSs), Natural wetland systems, Treatment mechanisms, Wetlands classification, Wetlands performance.

\section{INTRODUCTION}

Worldwide, engineered waste treatment systems designed to mimic natural ecosystems are increasingly becoming popular because of their environmental soundness as well as effectiveness $[1,2]$. They are also preferred because of their aesthetic appeal which contrasts sharply with conventional non-natural treatment systems. The observed trend is even more pronounced with the wetlands technology [3$5]$.

In Tanzania, there is currently an increasing body of knowledge on performance of engineered wetland systems (EWSs) [6-13] and pseudo-natural wetland systems (PWSs) [14]. There is also a considerable coverage on performance efficiency of experimental EWSs with respect to removal of organics, nutrients, and pathogens [15-17]. Moreover, general information and data on application potential of EWSs for waste treatment in Tanzania are outlined in Mbuligwe [18] and [19]. With respect to modelling, Mashauri and Kayombo [20] have reported on modelling of a wetland system coupled to a facultative waste stabilization pond at the University of Dar es Salaam. Other aspects on modelling of EWSs in Tanzania are reported in, among others, Kaseva [21]. There is also much information in the literature on attributes, functions, and values of natural wetland systems pertinent to Tanzania [5, 22-25]. However, comprehensive information on both EWSs and natural wetland systems that relates them to one another and to land and aquatic waste treatment systems is hard to come by in the literature.

*Address correspondence to this author at the School of Environmental Science and Technology, Ardhi University (ARU), P. O. Box 35176, Dar es Salaam, Tanzania; Tele: +255 22 2775447; Fax: +255 22 2775391; E-mails: kaseva@uccmail.co.tz; kaseva@aru.ac.tz
It has been observed that the available literature on wetland systems in Tanzania has misconceptions, gaps, and missing links that are likely to lead to a poor understanding and inappropriate application of the budding EWS technology. On the whole, the identified deficiencies in the literature pertain to the background on wetlands and their relation to aquatic and terrestrial ecosystems; their classification, which affects their applicability; and their mechanisms of pollutants removal.

The main objective of this paper is to correct some of the observed misconceptions, gaps, and inadequacies pertinent to the literature on wetlands. This paper fills in an important gap in the literature on wetlands in Tanzania because it addresses important aspects of wetlands that existing literature does not cover at all or cover inadequately. The paper draws on data and information from literature sources, field survey findings, and EWS performance assessment. It dwells on the background, classification, components, functions, treatment mechanisms, and performance as well as applicability of EWSs in Tanzania. Notably, the paper encompasses a discussion on mechanisms that affect pollutants removal in non-conventional EWSs like those employed in environmental remediation of contaminated sites. The paper also profiles treatment performance efficiency data for some existing EWSs. Furthermore, it discusses the applicability of the technology in Tanzania.

\section{ATTRIBUTES AND TRANSFORMATIONS OF NATURAL WASTE TREATMENT SYSTEMS}

\subsection{Background Information and Attributes of Natural Waste Treatment Systems}

This section seeks to discuss natural waste treatment systems in order to lay the ground for the discussion on wetland 
systems. This is important because wetland systems occupy a middle (transitional) position between the major aquatic and land ecosystems $[5,26]$ and can form from, or be transformed into, either of the land and aquatic ecosystems. An understanding of EWSs is clearly incomplete without sufficient background knowledge on these major ecosystems.

Natural systems in the context of waste treatment are described by Reed et al. [1] to be those processes that depend primarily on their natural components to achieve their intended treatment purpose. Notably, natural systems may make use of such not-so-natural components as pumps and piping for waste conveyance. However, their treatment responses do not typically depend exclusively on external energy sources [1]. The main distinguishing aspect between natural and conventional systems used in waste treatment is the source(s) of energy that predominate in the two treatment categories [3]. The energy for natural treatment systems typically rely on renewable energy, including solar radiation; the kinetic energy of wind as well as water; and storage of potential energy in biomass. Natural waste treatment systems include such unique processes as photosynthesis, photooxidation, and plant uptake, in addition to those that are common in even mechanical or in-plant treatment systems such as sedimentation, filtration, gas transfer, adsorption, ion exchange, chemical precipitation, chemical oxidation and reduction, and biological conversion and degradation [27]. On the other hand, conventional treatment systems encompass such operations as forced aeration, mechanical mixing, and/or use of chemicals [3]. Additionally, natural waste treatment systems are by far more land-intensive than the energy-intensive conventional waste treatment systems.

With regard to environmental concerns, the virtues of natural waste treatment systems are underlined by the fact that they are not associated with the main negative features of conventional waste treatment systems [1,3]. These include depletion of non-renewable resources; environmental degradation caused by the extraction and use of the nonrenewable resources; and impacts on the environment of residual by-products produced through the use of the conventional treatment technologies. Natural waste treatment systems fall under aquatic, terrestrial, and wetland systems $[1-3,27]$. Of the three types of natural waste treatment systems, treatment wetlands have received considerable attention and seen increased applications in the past few years all over the world, mostly in North America, Europe, Australia, and to a less extent in Asia and Africa.

\subsection{Aquatic Waste Treatment Systems}

Aquatic treatment systems make use of aquatic plants, animals (and microorganisms) as a component in a wastewater treatment system. Treatment is effected as a result of direct uptake of material by the biota as well as by their presence which alters the physical environment and enhances treatment processes [1, 2, 27]. Aquatic treatment systems are mainly stabilisation ponds and aquacultural systems. Aquacultural systems typically include hyacinth and duckweed ponds.

\subsection{Land Waste Treatment Systems}

Land treatment systems constitute application of waste to soils in a controlled manner to achieve treatment of certain wastewater constituents of interest [1, 2, 27]. The most common types of land treatment systems are: slow rate system (SRS); rapid infiltration system (RIS); and overland flow system (OFS). According to [1, 2, 26, 27], the SRS is the predominant form of land treatment system, and is provided as secondary or advanced treatment system. The wastewater is applied overhead by means of sprinklers or on the surface at an annual loading rate of $0.5-6 \mathrm{~m}$. The treatment area is planted with forage crops like grass, field crops like corn, or forest systems. Effluent is disposed of by evapotranspiration or through percolation. The systems can be designed to satisfy needs of crops planted or to meet the design limiting factor for a specific system.

The RIS is discussed at length in Metcalf and Eddy [1-3, 26], as summarised below. In RISs, wastewater is treated as it percolates through permeable soil. They are designed for treating secondary effluent or providing advanced treatment. RISs usually do not incorporate plants since the wastewater infiltrates at too fast a rate for effective plant uptake to occur. The wastewater is applied by means of sprinklers or on the surface at a rate of $6-12 \mathrm{~m}$ per year. The influent usually needs to be pre-treated in primary treatment systems or short detention ponds. However, aquatic pre-treatment is inappropriate since algae eventually reduce infiltration of the wastewater into the soil. The effluent is disposed of through recharge of streams and ground water, or may be recovered for reuse. Application schedules are in cycles of 1-2 days of application followed by 1-2 weeks of drying.

The OFS is also discussed at length in Metcalf and Eddy $[1-3,26,27]$, as outlined below. In overland flow systems wastewater is treated as it passes over a vegetated slope. Overland flow systems provide secondary or advanced treatment to reduce BOD and TSS or remove nutrients. Generally, they are $30-60 \mathrm{~m}$ in length and slopes are $2-8 \%$. Usually percolation is minimal, and detention time is in terms of hours. The wastewater is applied on the surface or overhead by means of sprinklers. Preliminary treatment is usually by means of fine screening or primary treatment. The effluent from OFS is discharged into streams, recycled or subjected to evapotranspiration. The whole OFS treatment area is planted with grass, which serve as colonising sites for bacteria. Types of grass depend on where the system is constructed and the types of grass available locally.

\subsection{Wetland Systems}

Wetlands are defined as land where the water table is at (or above) the ground surface long enough each year to maintain saturated soil conditions and the growth of related vegetation $[1,3,26,28]$. Conventionally, wetlands are classified as natural or constructed (engineered) wetland systems. According to [29] as well as [5], constructed wetlands, which are engineered ecosystems in which wetland plants and processes are manipulated by control of hydraulic conditions, come in two main types: free water surface and subsurface flow wetlands. Free water surface wetlands are not acceptable in some parts of the world as they can act as 


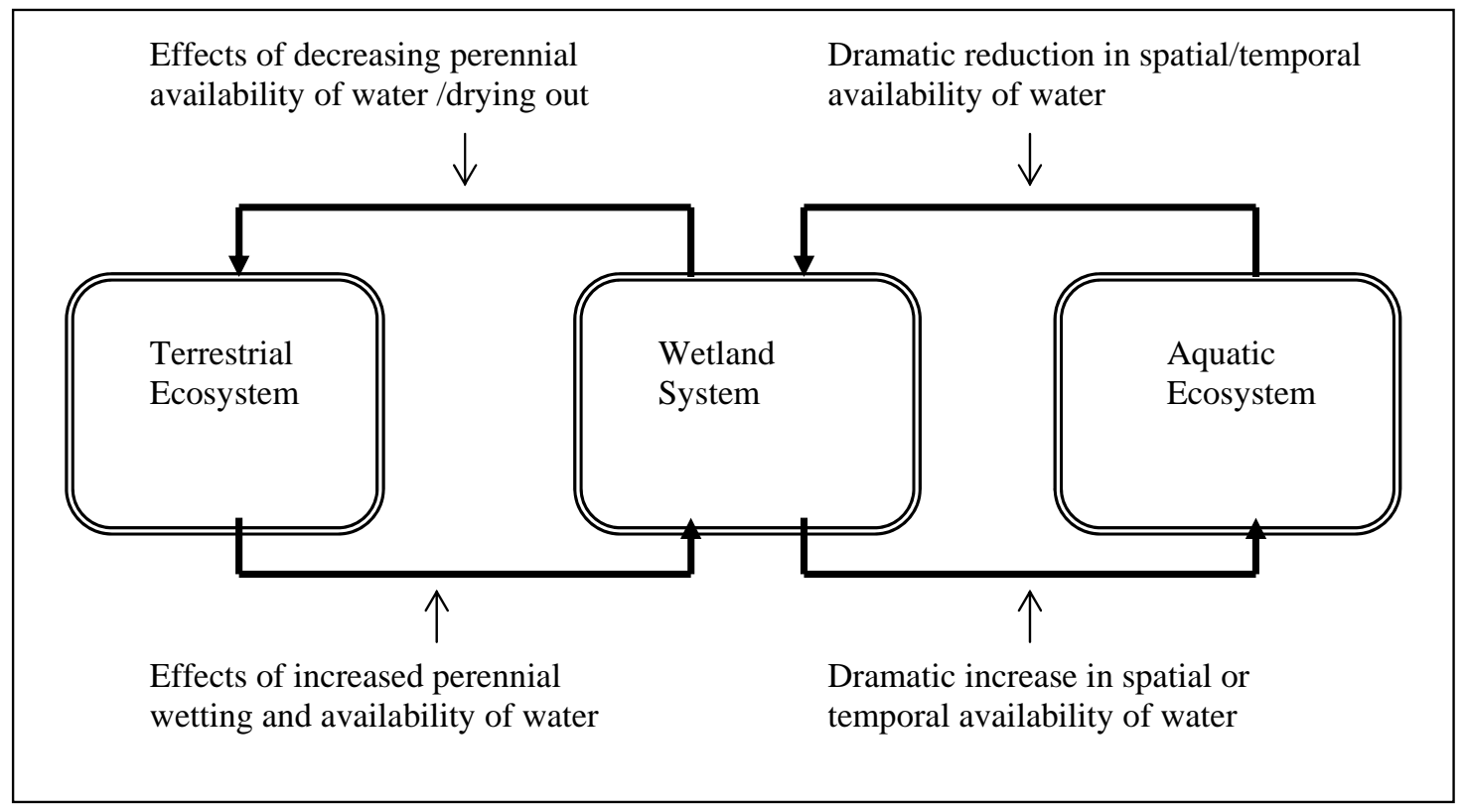

Fig. (1). Schematic illustration of ecosystem transformations in surveyed wetland systems.

breeding sites for insect disease vectors and require careful design to avoid short-circuiting [29].

\subsection{Transformations of Terrestrial and Aquatic Ecosys- tems into Wetland Systems}

A typical manifestation of natural waste treatment system transformation into a wetland system is exhibited by pseudonatural wetland systems (PWSs). PWSs result from ecosystem transformations caused by anthropogenic activities. The main cause has been identified as the discharge of nutrient rich wastewater from such sources as on-site sanitation systems [14]. Consequently, these pseudo-natural wetland systems are located close to the sources of the nutrient rich wastewater, and their creation is traced to the time the sources of the wastewater commenced discharging [14]. The surveyed pseudo-natural wetland systems exhibit features that relate them to transformations linking terrestrial ecosystems, terre-aquatic ecosystems (wetlands), and aquatic ecosystems as depicted by Fig. (1).

With reference to Fig. (1), the ecosystems can be transformed from one type into another through a process known in the ecological engineering circles as "self-design". In selfdesign, an ecosystem changes its dominant processes and the way it functions, its features and characteristics, and hence its very nature, in response to stresses imposed upon it by external agents as well as internal needs. It undergoes the changes in order to be able to cope with its changed environment. When, for example, a terrestrial ecosystem is overwhelmed by temporal dominance of presence of water, it changes into a terre-aquatic ecosystem (wetland system). On the other hand, if an aquatic ecosystem is temporally or spatially deprived of water it tends to change into a terre-aquatic ecosystem. The concept of self-design is related to "selforganisation", which Camazine et al. [30] define as a broad range of pattern-formation processes in both physical and biological systems, mainly through interactions internal to the system, without intervention by external directing influences.
According to [14], "pseudo-natural wetland systems (PWSs) have been identified as WSs that are seemingly natural, especially by virtue of their occurring as part of or alongside natural WSs. They are a product of unintentional anthropogenic modification of natural WSs or part of terrestrial ecosystems. They are clearly different from both the natural WSs and terrestrial ecosystems from which they evolved. They are also different from conventional artificial WSs since they have neither been designed nor constructed, and as such lack the regularity of pattern and provision of ancillary facilities pertinent to conventional artificial WSs. PWSs in Dar es Salaam City have been found to occur downstream of most unplanned settlements, which rely mostly on on-site sanitation systems. They are also found downstream of storm water and sanitary sewer outfalls and in the flow path of leachate from crude solid waste disposal sites. The PWSs in Dar es Salaam City have arguably developed from the influence of aquatic conditions imposed on terrestrial environments as a result of perennial discharges of water seeping out of the on-site sanitation systems, sewage flowing out of sewer outfalls, and leachate. The PWSs play an important role in pollution control, especially downstream of squatter areas using on-site sanitation systems.

The change from aquatic ecosystem into a wetland system was observed in WSP systems, a good example being the Vingunguti WSP system. Generally, solids including sand which enters the sewer through sanitary appliances where it is used for cleaning, and through manholes with storm water inflow, is present in great quantities in wastewater entering WSP systems. As a result, if not removed in time, solids tend to accumulate at the mouth of the inlet to the first pond, usually the anaerobic pond. With time, they form a mound that protrudes out of the surface of water. The size of the mound that develops depends on the concentration of the sand in influent wastewater and how long the sediments have been left uncollected. In the Vingunguti WSP, a mound of sediments was found to have grown so big and remained for so long that cattail plants, which are typical 


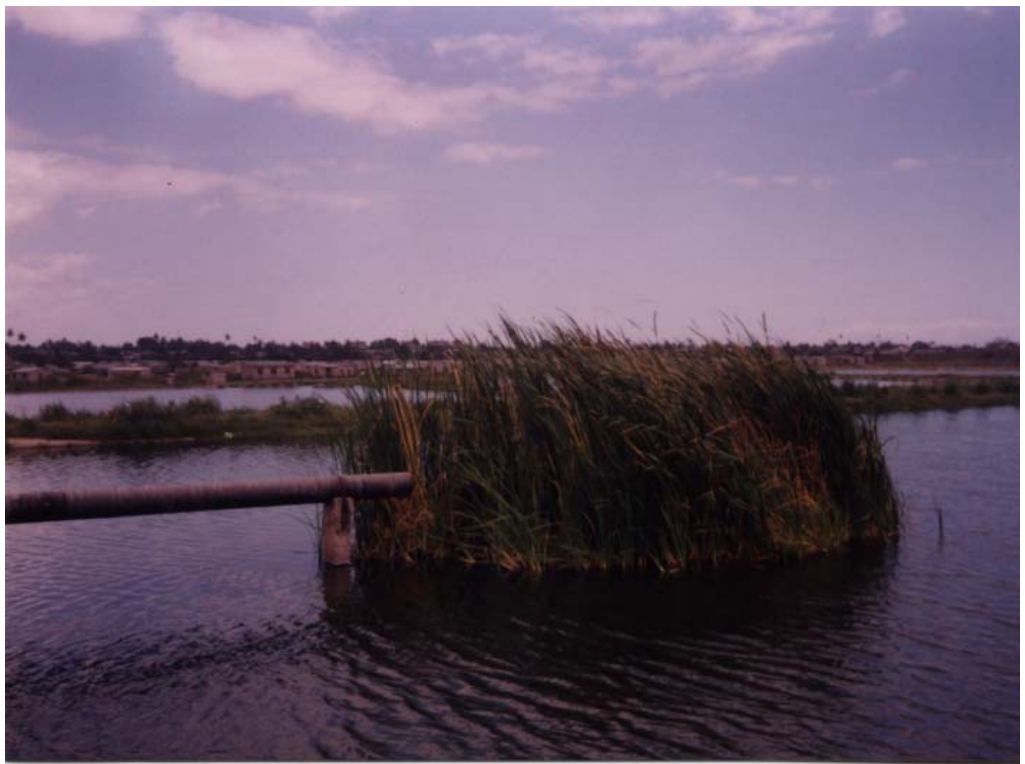

Fig. (2). Wetland System Island vegetated with cattail plants in the midst of Vingunguti WSP system first pond in Dar es Salaam City, Tanzania. The wetland system island is a result of partial ecosystem self-design following formation of a sediment mound at the pond inlet. The mound transformed an aquatic ecosystem into an aqua-terrestrial ecosystem. The pipe seen in the picture is the inlet pipe.

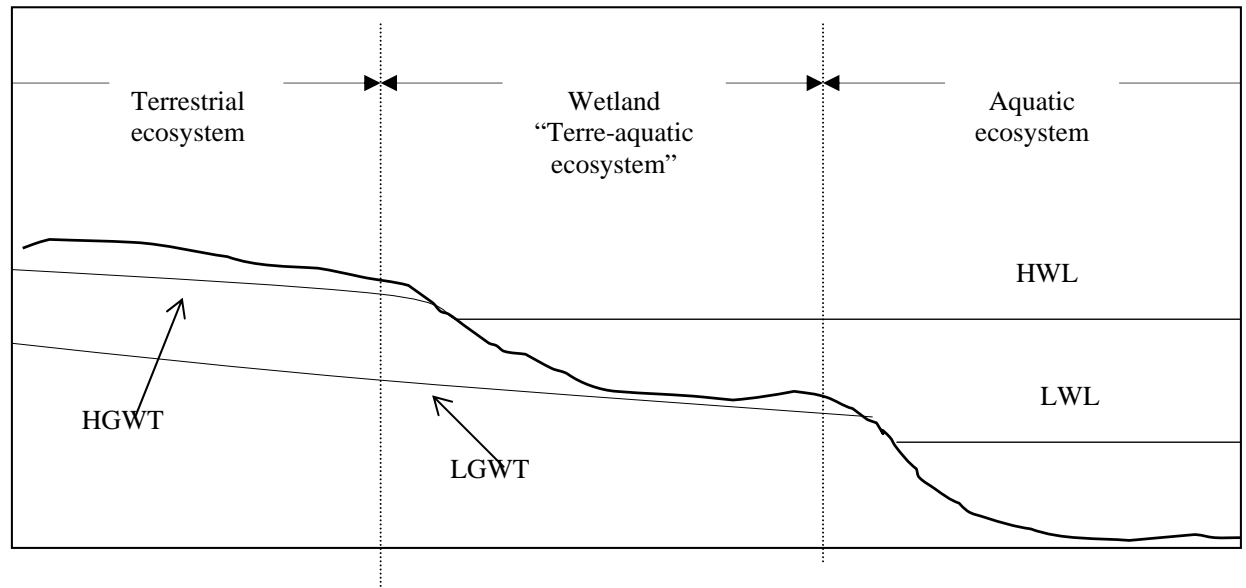

Fig. (3). Schematic illustration of the conceptual definition of wetlands. HGWT = highest groundwater table; HWL = highest water level; LGWT = lowest groundwater table; LWL = lowest water level.

wetland plants, fully colonised it forming an island wetland system in the midst of an aquatic ecosystem as shown in Fig. (2).

It is interesting to note that, in the Nakivubo swamp in Uganda, phenomena similar to the one represented by Fig. (2) are evident except that they occur in a natural system. Mats of Cyperus papyrus plants that float on water are so thick and extensive that people walk and carry out various activities on them without directly noticing that the mats float on a water body [22-24]. Mature Cyperus papyrus plants from the mats are harvested for use as roofing and walling materials.

\section{WETLAND SYSTEMS CLASSIFICATION AND FUNCTIONS}

\subsection{Basic Concepts and Definitions}

Although in the preceding sections a number of definitions of the term wetlands have been given, it is still consid- ered worthwhile to revisit the issue of definitions of wetlands. This is done for the purpose of taking note of the commonality and differences among the various definitions put forward in the literature. It is meant to reinforce the concept of what should be understood by the term wetlands. Banking on the concept of wetlands as transitional ecosystems (in spatial, hydrologic, and conceptual basis) between aquatic and terrestrial ecosystems, wetlands can conceptually be defined as illustrated in Fig. (3), which is similar to corresponding illustrations presented in Kadlec et al. [5, 26].

On the basis of Fig. (3), it can be surmised that wetlands are characterised by the fact that they have some features and attributes of both terrestrial and aquatic ecosystems. They also lack some other features and attributes of both terrestrial and aquatic ecosystems. More importantly, because of possessing or lacking some features and attributes, wetlands have unique features and attributes that cannot be found in either terrestrial or aquatic ecosystems [28]. On account of their spatial and hydrologic transitional nature, wetlands can 
Table 1. General Classification of Natural Wetlands

\begin{tabular}{|c|c|c|c|}
\hline \multicolumn{2}{|c|}{ Natural Salt Water Wetlands } & Natural Freshwater Wetlands \\
\hline Salt Marsh & Forested Saltwater or Mangrove & Freshwater Marsh & Freshwater Swamp \\
\hline \hline $\begin{array}{c}\text { Saltwater wetlands dominated by } \\
\text { emergent (rooted and extending } \\
\text { above the level of water), herba- } \\
\text { ceous (soft tissue, non woody) } \\
\text { plant species }\end{array}$ & $\begin{array}{c}\text { Salt water wetlands dominated by } \\
\text { woody plant species (typically man- } \\
\text { grove forests) }\end{array}$ & $\begin{array}{c}\text { Freshwater wetlands dominated by } \\
\text { emergent, herbaceous plant species } \\
\text { adapted to intermittent to continuous } \\
\text { flooding. }\end{array}$ & $\begin{array}{c}\text { Freshwater wetlands dominated by } \\
\text { tree species adapted to life in in- } \\
\text { frequent to prolonged flooded } \\
\text { conditions. }\end{array}$ \\
\hline
\end{tabular}

characteristically be referred to as aqua-terrestrial ecosystems.

Formal definitions of the term wetlands are almost as many as the types of wetlands identified. Metcalf and Eddy [27] defne wetlands as inundated land areas with water depths typically less than $0.6 \mathrm{~m}$ that support growth of emergent plants such as cattail, bulrush, reeds, and sedges. According to [1] wetlands are land where the water surface is near the ground surface for long enough each year to maintain saturated soil conditions, along with related vegetation. Wetlands can also be referred to as land areas that are wet during part or all of the year because of their location in the landscape [3]. Mitsch and Gosselink [5] note that "wetlands have unique features, the most notable of which are the presence of standing water for some period during the growing season, unique soil conditions, and organisms, especially vegetation, adapted to or tolerant of saturated soils". Mitsch and Gosselink [5] further sum up the essence of definitions of wetlands, pointing out that all of them essentially include three important components that distinguish wetlands from terrestrial and aquatic ecosystems. The distinguishing components are: the presence of water, unique soil conditions, and the fact that wetlands support vegetation adapted to their unique hydrologic conditions. Patrick [28] sums up the discussion on definitions of wetlands asserting that, any definition of wetlands must include a statement about the dominance of water, the presence of wet soils, and the presence of plants that are capable of growing under these conditions.

The Ramsar Convention definition of wetlands, which is quoted by Mitsch and Gosselink [5] is as follows: "area of marsh, fen, peatland or water, whether natural or artificial, permanent or temporary, with water that is static or flowing, fresh, brackish, or salt including areas of marine water, the depth of which at low tide does not exceed $6 \mathrm{~m}$ ". It is noteworthy that, the last part of the Ramsar Convention definition on $6 \mathrm{~m}$ depth is meant to exclude water bodies that qualify as aquatic ecosystems. The Ramsar Convention definition could interestingly be compared to the definition given by the United States Corps of Engineers, which is also quoted by Mitsch and Gosselink [5]. This goes as follows: "wetlands are those areas that are inundated or saturated by surface or groundwater at a frequency and duration sufficient to support, and that under normal circumstances do support, a prevalence of vegetation typically adapted to life in saturated soil conditions. Wetlands generally include swamps, bogs, and similar areas".

Constructed or engineered wetland systems are meant to offer all of the treatment capabilities of natural wetlands but without the constraints associated with the discharging to natural ecosystems [27]. Constructed wetlands are put up where none existed before, and although they can have habitat value they are intended primarily for wastewater treatment [1]. Constructed wetlands are specifically designed and implemented with water quality improvement as the primary goal $[3,5]$. In the European context, Cooper et al. [31] define constructed wetlands and reed beds as designed and man-made systems which are aimed at simulating the treatment that has been observed to take place when polluted water is allowed to enter a natural wetland system. Mitsch and Gosselink [5] note that wetlands can be used to treat municipal wastewater, small-scale rural wastewater, acid mine drainage, landfill leachate, and non-point source pollution from both urban and agricultural run-off. Wetlands are increasingly becoming popular because they are deemed to be of low cost in terms of both capital and operating costs, and less involving in terms of operational and maintenance needs [31]. Additionally, they are considered to constitute green processes, and this fits in well with environmental correctness, and they can improve landscape and scenic quality of their neighbourhood.

\subsection{Types and Classification of Wetlands}

Wetlands types and classifications are normally discussed on the basis of a number of criteria including hydrologic and hydraulic properties or behaviour, functions, types and characteristics of their media or plants, spatial attributes, and salinity of water. Some of these classifications and types have got more to do with their origin than their utility in the practice of the wetlands technology. As noted in earlier discussions, generally wetlands can be either natural or artificial (non-natural). Also, wetlands that can be referred to as pseudo-natural wetlands have been reported by Mbuligwe [14]. Under the artificial type of wetlands fall constructed (engineered) wetlands and the so-called created wetlands as noted by Kadlec and Knight [3] and [5]. Restored wetlands are basically natural wetlands recreated after having been disrupted by anthropogenic activities [5].

Kadlec and Knight [3] have classified wetlands into two categories each with its subcategories. The main categories are freshwater wetlands and saltwater wetlands. The former category refers to those that are inundated with freshwater (salinities less than $1000 \mathrm{mg} / \mathrm{L}$ ) the latter class refers to those that are inundated with brackish or saline water (salinities more than $1000 \mathrm{mg} / \mathrm{L}$ ). Subcategories of natural freshwater and salt-water wetlands are as presented in Table $\mathbf{1}$.

An important thing to take note of with respect to Table $\mathbf{1}$ and other discussions on types and classifications of wetlands is that, all types of wetlands are unified by the envi- 


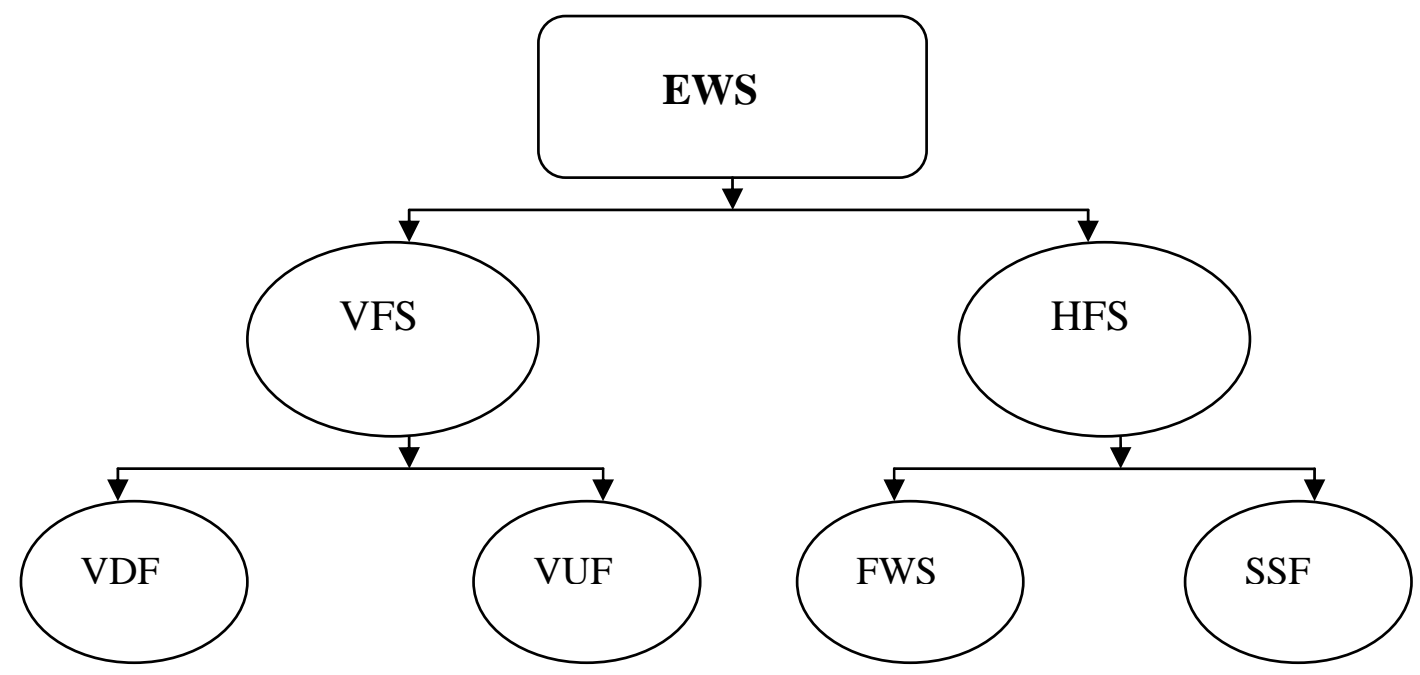

Fig. (4). Schematic classification of engineered wetland systems. EWS = engineered wetland systems; VFS = vertical flow wetland systems; HFS = horizontal flow wetland systems; VDF = Vertical downward flow wetland systems; VUF = vertical upward flow wetland systems; $\mathrm{FWS}=$ free water surface wetland system; SSF = sub-surface flow wetland system.

ronmental factors that control them. These are identified by Keddy and Fraser [32] as water levels; soil fertility; disturbance; salinity; grazing and burial. Considering the above factors, Keddy and Fraser [32] have come up with four principles for the management of wetlands, which consider water level fluctuations, fertility, competitive hierarchies, and centrifugal organisation.

\subsection{Engineered Wetland Systems (EWSs)/Constructed Wetlands Systems (CWSs)}

Engineered wetland systems (EWS) popularly known as constructed wetlands $(\mathrm{CW})$ are those wetland systems conceived, planned, designed, implemented (constructed), and operated as well as maintained for their specific objective such as wastewater treatment. The term constructed wetlands is a misnomer and highly misleading despite its popularity, which is evidenced by its established use internationally and as noted by Cooper [33]. The term gives the wrong impression that wetland systems that belong to this type are simply constructed without much of planning and design, and once in place they are left to fend for themselves. In connection with this issue, it is worthwhile to take note of the observation made by Cooper et al. [34] that engineered wetlands are not meant to be constructed and then left to operate without proper care. Apparently, this has made some of systems implemented in Europe to fail [34]. Reed et al. [1] argue that, by its very concept, an engineered wetland system is expected to perform better than a natural one of equal area, and process reliability should be improved because wetland plants and other system components can be managed as required. Reed et al. [1] further note that, with engineered wetland systems it should be possible to improve performance through operation modifications, and when there is no need for the system it should be possible to decommission it, just as it is possible with other waste treatment concepts.

An outline of some historical facts pertinent to the development of the engineered wetlands technology is in order here. To start with, it is almost indisputable that the engineered wetlands technology started in Germany [3, 31, 34, 35]. However, natural wetlands have been in use as recepta- cles of wastewater from human habitats since the advent of sewerage systems, which is more than 100 years [3]). Kathe Seidel is credited with the initial scientific studies on the use of wetlands for wastewater treatment at Max Plank Institute in Germany [3, 35, 36]. Between 1952 and the late 1970s Seidel investigated the use of wetland plants, mainly Scirpus lacustris (bulrush) in the removal of phenols from wastewaters and treatment of dairy wastewater [35, 36]. Evidently, Seidel's work had so far reaching impacts that in 1975 she was invited to consult on the design of a wetland system for polishing wastewater in Philadelphia in the USA [35]. The history of the wetlands technology in the USA can be said to have begun in the 1970s with the involvement and support of the US Environmental Protection Agency (EPA), the US Army Corps of Engineers, the National Science Foundation, and the US Department of Agriculture [36]. According to [34] reed beds and engineered wetland systems became really popular as a technology for treating domestic wastewater in Europe in the mid-1980s.

In the UK, the EWS technology started with adaptation of the so-called horizontal flow reed bed treatment systems (RBTS), which were the Root Zone Method (RZM) [31], [34]. The RZM process was developed at the University of Hessen by Professor R. Kickuth [34] who was once a student of Kathe Seidel [35]. In the UK the wetlands technology was popularised by such organisations as WRc [31, 34]. In the US it was promoted first by Seidel herself and later by such people as John Kadlec [36]. More useful details on the historical background of engineered wetland systems are well documented in Bastian and Hammer [3, 31, 34, 36].

The broadest classification of engineered wetland systems groups them into horizontal flow (HF) and vertical flow (VF) wetland systems [26, 31, 34, 37]. Surprisingly most of the available literature, especially that reporting on practice in North America (for example [1-3, 5, 27]) focuses on $\mathrm{HF}$ wetland systems as if VF wetland systems do not exist at all. Suthersan [37] mentions about VF wetland systems but still states that the main types of engineered wetland systems are SSF and FWS ones. One convenient way to group engi- 
Table 2. Functional Definitions of Types and Sub-Types of Engineered Wetland Systems

\begin{tabular}{|c|c|c|c|c|}
\hline \multicolumn{2}{|c|}{ Wetland System Type } & \multirow{2}{*}{ Wetland System Main Distinguishing Feature } & \multirow{2}{*}{$\begin{array}{c}\text { Main/specific Applica- } \\
\text { tions }\end{array}$} & \multirow{2}{*}{$\begin{array}{l}\text { Relevant Refer- } \\
\text { ences }\end{array}$} \\
\hline Main Types & Sub-Types & & & \\
\hline \multirow{2}{*}{$\begin{array}{l}\text { Horizontal flow (HF) } \\
\text { wetland system }\end{array}$} & $\begin{array}{l}\text { Free water surface } \\
\text { flow (FWS) }\end{array}$ & $\begin{array}{l}\text { Wastewater flows horizontally through the sys- } \\
\text { tem for treatment; the water surface is always } \\
\text { above the wetland media top level. }\end{array}$ & $\begin{array}{l}\text { Secondary and tertiary } \\
\text { level conventional waste- } \\
\text { water treatment applica- } \\
\text { tions }\end{array}$ & $\begin{array}{c}{[1-3,5,26,27,31,} \\
33-35,37,47]\end{array}$ \\
\hline & $\begin{array}{l}\text { Sub-surface flow } \\
\quad(\mathrm{SSF})\end{array}$ & $\begin{array}{l}\text { Wastewater flows through the system for treat- } \\
\text { ment horizontally, but the water surface is always } \\
\text { below the wetland media top surface }\end{array}$ & $\begin{array}{l}\text { Secondary and tertiary } \\
\text { level conventional waste- } \\
\text { water treatment applica- } \\
\text { tions }\end{array}$ & $\begin{array}{l}{[2,3,5,26,27,31,} \\
33,34,35,37,47]\end{array}$ \\
\hline \multirow[t]{2}{*}{$\begin{array}{l}\text { Vertical flow (VF) } \\
\text { wetland system }\end{array}$} & $\begin{array}{l}\text { Vertical downflow } \\
\text { (VD) }\end{array}$ & $\begin{array}{l}\text { Wastewater flows through the wetland system for } \\
\text { treatment in the downward direction, and the flow } \\
\text { is applied intermittently }\end{array}$ & $\begin{array}{l}\text { Secondary and tertiary } \\
\text { level conventional waste- } \\
\text { water treatment applica- } \\
\text { tions }\end{array}$ & {$[5,31,33,34,37,47]$} \\
\hline & Vertical upflow (VU) & $\begin{array}{l}\text { Wastewater flows through the wetland system for } \\
\text { treatment in the upward direction. The flow is } \\
\text { applied continuously. }\end{array}$ & $\begin{array}{l}\text { Treatment of wastewater } \\
\text { containing volatile sub- } \\
\text { stances such as VOCs }\end{array}$ & [40] \\
\hline
\end{tabular}

neered wetland systems according to their types with a view to rectifying the deficiencies noted in the literature is as shown in Fig. (4). Table 2 elaborates the classification given in Fig. (4) by way of functional definitions coupled with brief descriptions as well as relevant references.

HFSs are effective for removing BOD, suspended solids, and bacteria as well as for nitrification and denitrification [33]. On the other hand, VDSs are very effective for nitrification, and their efficiency is very high compared to that of HFSs. As such, a wetland system that is intended to remove nutrients has to essentially include a VFS unit.

It can be noted that the types of engineered wetland systems outlined in Table $\mathbf{2}$ are mainly classified according to their hydrologic and hydraulic attributes. This is not surprising because hydrology is the main determinant of wetlands $[3,5,26]$. Principles behind both the VF and $\mathrm{HF}$ wetland systems are discussed at length in the literature as indicated in Table 2. Cooper et al. [31] and Cooper et al. [34] have discussed VF wetlands systems in an exceptionally detailed manner. HF wetland systems are discussed in almost all the literature on constructed wetlands. An obviously notable thing for those who have seen wetland systems used in Europe as opposed to those used in North America and Australia is that, they are markedly different in a number of ways, including size and type. Cooper et al. [31] and Cooper et al. [34] note that in North America and Australia generally the wetland systems applied are FWS ones, are very large in size, and are principally meant for tertiary level treatment for wastewater generated by towns and cities. In Europe the wetlands are mainly SSF systems, are smaller in size, and are mainly used for secondary treatment of effluent from small populations. Some of the systems in Europe are coupled to septic tank systems. Cooper et al. [34] point out that, because of some similarities between application situations in developing countries and Europe, developing countries might be better off if they adopt European rather than North American and Australian types of wetland systems. Cooper et al. [34] assert that SSF wetland systems have proved to be the most effective and more compact systems except in the case of treatment of highway runoff where FWS wetland systems can be more effective. Mitsch and Gosselink [5] point out the appeal of SSF wetland systems in Europe as being due to 1) natural wetland systems (that could be used) are harder to come by in Europe because most of them were destroyed, and 2) land is in short supply in Europe. In connection with this discussion, it is worth noting that unlike SSF wetland systems, FWS wetland systems, which are popular in North America, are associated with mosquitoes. Mosquitoes can be a very serious threat in the tropics where malaria fever kills many people [1, 2]. Mosquitoes associated with wetlands are also recognised to be a potential cause of health problems even in Australia [38].

Vertical upflow wetland systems have not been covered much in the literature. They are an emerging type of engineered wetland system and are well described in Kassenga et al. [39]. Engineered wetland systems can also be classified on the basis of the general type of wastewater (or sludge) they treat $[5,26]$. This classification includes municipal wastewater wetlands, industrial wastewater wetlands, mine drainage wetlands, stormwater and nonpoint source wetlands, landfill leachate wetlands, agricultural wastewater wetlands, and sludge and septage treatment wetlands.

\subsection{Wetland System Components and Functions}

The system components that are deemed to influence treatment processes in a wetland system are identified in similar ways by Reed et al. [1, 3, 5, 37]. The components are mainly wetland plants, soils (wetland media), the strata underlying the soil, detritus resulting from dying plants, and the 
water. Water that floods part or all of the wetland is an important component of a natural wetland as noted by Kadlec and Knight [3] and [26]; after all wetlands are largely driven by their hydrology [5]. The water that floods wetlands is also an important component of engineered free surface water wetland systems. Wetland plants which are vascular, rooted hydrophytes emerge above the water surface. There a host of wetland plant types, but the commonest with respect to engineered wetland systems and most relevant to this paper are cattails (Typha sp.) and reeds (Phragmites sp.). The wetland medium (soil) is a treatment medium as well as a means of support for wetland plants. It contains both organic and mineral components, and notable plant parts such as roots, rhizomes, and tubers. In most of natural wetlands most of the nutrients required for the growth of wetland plants can be obtained from the soil by emergent wetland plants [1]. In engineered wetland systems void spaces in the media provide the flow channels in the SSF wetlands. Detritus forms as a result of accumulation of live and dead organic material such as dead emergent plant material, dead algae, living and dead invertebrates, and microorganisms such as bacteria and fungi [26]. Water is the lifeline of wetlands since it influences wetland processes and is essential for all living things. The unaltered organic, mineral or lithic layers underlying wetlands need to be impervious to or saturated with water for maintaining proper hydrologic conditions above it where the active rooting zone of wetland vegetation form [26].

\subsection{Wetland Systems Values}

Wetlands have many uses and benefits, which have also been discussed at length in the literature. Mitsch and Gosselink [5] consider wetland values on the basis of three levels which they identify as population, ecosystem, and global. Wetland system values in Tanzania are discussed at length in Kassenga [25] and Mbuligwe [12].

\subsection{Mechanisms of Pollutants Removal in Conventional Wetland Systems}

In a wetland system pollutants removal is achieved by a combination of effects of wetland components, including the wetland media and litter, wetland plants, and microorganisms. Pollutants are removed by a complex variety of physical, chemical, and biological processes [1-3, 26, 31, 34, 35]. These include:

- Sedimentation of suspended particulate matter;

- Filtration and chemical precipitation through contact of the water with the substrate and litter;

- Chemical transformation;

- Adsorption and ion exchange on the surface of plants, substrate, sediment, and litter;

- Aerobic and anaerobic breakdown, and transformation and uptake of pollutants and nutrients by microorganisms and plants;

- $\quad$ Predation of pathogens by other organisms such as protozoa;

- Natural die-off of pathogens;

- Excretion of antibiotics from roots of some wetland plants also known as phytotoxicity;

- Volatilisation; and
- UV irradiation of pathogens by solar energy, especially for parts of wetland systems close to the surface. Notably, this disinfection mechanism is not effective if the solar UV cannot get through to the water.

It is possible and desirable to engineer a wetland system to maximise the particular removal mechanism required for the treatment of a particular wastewater constituent [34]. Manipulation of a wetland system for removal of a specific pollutant is possible at both design and operation stages, but it should be most feasible and effective at design stage. More detailed discussions on some of the pollutants removal mechanisms outlined in this section are presented in the next section.

\subsection{Mechanisms of Pollutants Removal in Emerging En- gineered Wetland Systems}

There are increasing trends to use EWSs in the treatment of non-conventional pollutants and special purpose applications. These include treatment of chlorinated VOCs in upflow wetlands [39, 40], treatment of acid mine drainage [5], treatment of landfill leachate [41], and in-situ remediation of pollution plumes, contaminated soil and aquifers [5, 37, 42]. One of the promising trends in hazardous waste management and remediation engineering is to treat VOCs in upfow engineered wetland systems. One of the reasons for this practice is minimisation of volatilisation. Another reason is to create anaerobic environments suitable for microorganisms that dechlorinate VOCs like TCE and PCE and their degradation products.

The main fate and transport processes that can affect contaminants in the treatment environments and systems listed above are advection, dispersion, diffusion, sorption, volatilisation, biodegradation, and abiotic degradation as discussed in Suthersan [37, 43, 44].

Advection is the movement of the contaminant as a result of movement of the bulk of the water in which it is dissolved. This is the main mechanism recognised for facilitating the movement of contaminants in the subsurface, and it is independent of contaminant properties $[43,44]$. It depends on media properties, which are mainly hydraulic conductivity, $K$; effective porosity, $n_{e}$, and hydraulic gradient, $d H / d L$. Advection can be related by seepage velocity, $v_{x}=$ $\left(K / n_{e}\right)(d H / d L)$.

Dispersion describes the mixing due to movement of the water as well as heterogeneities in the media. It depends on properties of the media and scale observation, but it does not depend on characteristics of the contaminant. Dispersion results in longitudinal, transverse, and vertical spreading of a contaminant plume. It also causes a reduction in contaminant concentration. Dispersivity, $\alpha_{x}$ can be estimated by expressions $\alpha_{x}=0.083\left(\log 10 L_{p}\right)^{2.414}$ or $\alpha_{x}=0.1 L_{p}$, where $L_{p}$ is the plume length $[43,45]$.

Diffusion happens through movement and dilution of the contaminant as a result of molecular diffusion. Unlike advection and dispersion, diffusion depends on properties of the contaminant as well as on concentration gradients. Diffusion can be quantified using Fick's laws represented by: $F=$ $D(d C / d x)$ (first law) and $(d C / d t)=D\left(d^{2} H / d x^{2}\right)$ (second law), 
where $F=$ contaminant flux, $D=$ coefficient of diffusion. Diffusion is considered to be unimportant compared to dispersion at most groundwater velocities [43-45].

Sorption occurs due to reaction between media matrix and contaminant as a result of which relatively hydrophobic organic compounds become sorbed to organic carbon or clay
For designing an upflow wetland system for treating VOCs with consideration for biodegradation and sorption, Equation 1 can be solved for boundary conditions $C(0, t)=$ $C_{o}$ for $t>0$ and $\partial \mathrm{C} / \partial \mathrm{x}=0$ for $x=\infty$, and initial conditions $\mathrm{C}(x, 0)=0$ for $x \geq 0$, giving the expression in Equation 2 [45].

$$
C=\frac{C_{o}}{2} \exp \frac{\left(u_{x}-v t\right) x}{2 D_{x}} \operatorname{erfc}\left[\frac{R x-v t}{2 \sqrt{D_{x} R t}}\right]+\frac{C_{o}}{2} \exp \frac{\left(u_{x}+v\right) x}{2 D_{x}} \operatorname{erfc}\left[\frac{R x-v t}{2 \sqrt{D_{x} R t}}\right]
$$

minerals. Sorption has the effect of retarding the contaminant within the wetland media, making it available for degradation longer than the hydraulic retention time of water. It also effectively removes the contaminant from the water. Sorption can be related through: $R=\left(1+\left[\begin{array}{ll}\rho_{b} & K_{d}\end{array}\right] / n\right)$, where $R=$ retardation coefficient, $\rho_{b}$ bulk density $(\mathrm{kg} / \mathrm{L}), K_{d}=$ distribution coefficient $(\mathrm{L} / \mathrm{kg})$ of the contaminant, and $n=$ porosity. $K_{d}=f_{o c} k_{o c}$ where $f_{\text {oc }}=$ organic carbon fraction and $k_{o c}$ $=$ normalised octanol-water partitioning coefficient. Due to sorption, the velocity of the contaminant, $v_{c}$ is less than the seepage velocity by a factor of $1 / R$.

Volatilisation occurs when the contaminant dissolved in the water transfers into the vapour phase, and eventually into the atmosphere. The expression $C_{a}=H C_{l}$ can be used to quantify volatilisation, and it also indicates factors that influence volatilisation. In the equation, $C_{a}=$ vapour phase contaminant concentration, $C_{l}=$ liquid dissolved contaminant concentration, and $H=$ Henry's law constant.

Biodegradation refers to microbially mediated oxidation and reduction reactions that lead to degradation of the contaminant. Biodegradation has the potential to effect complete degradation of contaminants, and it is considered to be the most important process. Biodegradation can be expressed as a first order reaction; $C=C_{o} e^{-k t}$. $C_{o}$ and $C$ are concentrations of the contaminant corresponding to the initial time and after time $t$ has elapsed, while $k$ is the first order reaction constant. Biodegradation depends on water chemistry, microbial population characteristics, and contaminant properties, and it can take place under aerobic as well as anaerobic conditions. Notably, phytoremediation fosters biodegradation. The rhizosphere is a suitable habitat for microorganisms that feed on root exudates and use oxygen that is released by the roots. These microorganisms are responsible for mediating the biodegradation processes. Abiotic degradation refers to chemical reactions that lead to partial or complete degradation of contaminants, but at typically slower rates than biodegradation. Abiotic biodegradation is dependent on the chemistry of the water and contaminant properties [43].

Based on the above outlined contaminant fate and transport processes, an equation that combines the most important processes can be derived. A typical hydrodynamic transport equation that includes a provision for first order biodegradation process can be written as shown in Equation 1.

$$
\frac{d C}{d t}=\frac{u_{x}}{R} \frac{\partial C}{\partial x}+\frac{D_{x}}{R} \frac{\partial^{2} C}{\partial x^{2}}-\frac{k}{R} C
$$

$$
v=u_{x}\left[1+\frac{4 \times k \times D_{x}}{u_{x}^{2}}\right]^{\frac{1}{2}}
$$

A simplification of Equation 2 has been proposed by Kassenga [40] for use in design of upflow engineered wetland systems. The resulting simplified design equation is Equation 4.

$$
C=C_{o} e^{-\left(k R\left(\frac{x}{u_{x}}\right)\right)}
$$

In Equations 2 and 4, $C=$ concentration of the pollutant at a vertical distance $x, C_{o},=$ the initial concentration of the pollutant at distance $x=0, k=$ lumped temporal degradation rate constant of pollutant, $R=$ retardation coefficient, and $u_{x}$ $=$ seepage velocity. It is important to realize that every pollutant has practically different $k$ and $R$ values. However, when designing an EWS for treating a wide range of pollutants, the designer must adopt design criteria for the worst case scenario, which is associated with the worst $k$ and $R$ set.

\subsection{Environmental Biotechnology and Wetlands}

Microorganisms are the single most important treatment component of wetland systems since they are for the most part responsible for the direct degradation of pollutants. The application of environmental biotechnology techniques to enhance the performance of wetlands encompasses a whole range of techniques from manipulating environmental conditions to favour certain microbial consortia to direct bioaugmentation. At the lower end of the scale of these techniques, there is the commonest and probably the simplest technique. This entails discrimination of microbial population by maintaining aerobic or anaerobic conditions through supplying or withholding oxygen. The simple selection of EWS types can be used to achieve this. When making the selection it is important to realise that FWS wetland systems are dominated by aerobic conditions, especially within the shallow water column. In SSF EWS's, both anaerobic and aerobic conditions have significant biochemical influences that have an impact on treatment effectiveness. VDF EWS's are dominated by aerobic conditions while VUF EWS's are practically dominated by anaerobic conditions. The preceding discussion explains why chlorinated VOCs would, as explained earlier [46] be treated in VUF EWS's. 
Bioaugmentation, in the wetlands case is basically the inoculation of a wetland system with a microbial culture with desired traits which is from another place (or enriched in the laboratory) to achieve specific treatment goals. For example, a microbial culture containing or enriched for Dehalococcoides ethenogenes can be introduced into an EWS enable it to treat TCE or PCE and their degradation products to ethene. In practice, two bioaugmentation approaches are considered feasible. One approach is to introduce the inocula of interest with the wastewater to be treated and let the microorganisms establish themselves in the wetland media. This method is advantageous for anaerobes since it minimises their exposure to aerobic conditions. However, slurry that is rich in microbial populations of interest cannot be easily introduced this way due to clogging problems.

The second method entails mixing the slurry rich in the desired microbial species with the wetland media just before installation of the media in the EWS. This approach avoids the main weakness of the first method, but it may be unfavourable if the inocula consist of obligate anaerobes. The efficacy of the first method depends on the speed with which microbial species of interest can establish themselves in the wetlands after being introduced in rather dilute concentrations. On the other hand, the efficacy of the second option depends mostly on the resilience and survival rate of the anaerobes after exposure to atmospheric oxygen and other associated harsh environmental conditions. If EWSs are used to treat wastewater, particularly industrial wastewater, that contains pollutants that can be taken up by wetland plants which can in turn be eaten by animals, there is a risk of introducing xenobiotics into wildlife and the food chain. For domestic wastewater, the risk is obviously significantly lower.

\section{PERFORMANCE EFFICIENCY PROFILE OF EWS'S IN TANZANIA}

Although EWSs have not been around for long in Tanzania, it is worthwhile to profile their performance efficiency on the basis of data available from monitoring full scale as well as experimental EWSs. Tables $\mathbf{3}$ and $\mathbf{4}$ present performance data based on research and monitoring done by researchers working at ARU and the University of Dar es Salaam. Notably, most of the data are based on experimental systems, which is understandable since the EWS technology is in its nascent stage in Tanzania.

In Table 3, the wastewater identified as domestic ST treated wastewater was domestic wastewater treated in three chamber STs for 2 days before being treated in the EWSs. In the EWS it was treated for 1.5 days in serial beds of reeds planted in coarse gravel $\left(\mathrm{d}_{\mathrm{c}}=25 \mathrm{~mm}\right)$ and cattail planted in fine gravel $\left(\mathrm{d}_{\mathrm{c}}=10 \mathrm{~mm}\right)$. Notably, both the STs and EWS were full scale systems. The EWSs treating raw textile wastewater was planted with cattails and cocoyam plants and had river sand media. Hydraulic loading rates and hydraulic retention times were $15-31 \mathrm{~cm} /$ day and $1.21-1.5$ days (calculated on the basis of wastewater flow rate and EWS unit dimensions), respectively. The data in Table 3 above compare well with those reported in the literature [1, 3, 26, 47].

In Table 4, some of EWSs whose data are reported had coarse gravel media and were planted with either cattails or reeds while others had sharp sand media and were planted with either coco yam plants or cattails. Hydraulic loading rates and hydraulic retention times were $15-31 \mathrm{~cm} /$ day and 1.21-2.5 days, respectively. The performance data outlined in Table $\mathbf{4}$ compare well with those reported in the literature $[1,3,26,47]$, except for the FC and TC data.

The rather low removal rates of $\mathrm{FC}$ and $\mathrm{TC}$ shown in Table $\mathbf{4}$ compared to those shown in Table $\mathbf{3}$ are attributable to differences in the media used. The FC and TC data reported in Table $\mathbf{3}$ are based on monitoring EWSs packed with sand while Table 4 reports on EWSs whose media were several times larger than sand. Sand has a higher filtration effect which removes TC and FC more effectively than coarser media.

Experimental EWSs treating effluent from WSPs at the University of Dar es Salaam have been reported to remove $42-74 \%$ of COD, $45-87 \%$ of suspended solids, $25-93 \%$ of TC, and 27-95 \% of FC [15]. Pilot scale EWSs vegetated with Typha and Phragmites plants and treating septic tank effluent reported by Kaseva et al. [10] removed COD by an average of $70 \%, \mathrm{BOD}_{5}$ by $74 \%$, TC by $75 \%$, and $\mathrm{FC}$ by $66 \%$. Those treating UASB effluent removed TC by $53-56 \%$ and $\mathrm{FC}$ by $62-67 \%$ [11].

\section{APPLICABILITY OF EWS'S IN TANZANIA}

\subsection{Rationale, General Considerations, Treatability and Scope}

Sanitation problems in Tanzania that require on - site sanitation systems imply that there is room for EWS's as an alternative or replacement effluent treatment system [6], [12]). On the other hand, the performance data for EWSs shown in Tables $\mathbf{3}$ and $\mathbf{4}$ indicate that EWSs can be applied in Tanzania to treat domestic as well as textile wastewater. However, the fact that the technology is rather new and there are some knowledge gaps, suggests a need for being cautious when adopting it. Nevertheless, the fact that EWSs have proved their efficacy in other parts of the world under conditions comparable or even more unfavourable than those in Tanzania, reaffirm that the technology is ripe for adoption.

Unlike the impression given by the publications cited in Tables $\mathbf{3}$ and 4, the scope of EWS applications in Tanzania need not be confined to domestic and textile wastewater. The application of EWSs in Tanzania needs to take into account all sources of wastewater that is amenable to treatment in EWSs. Notably, for obvious reasons, it is better to treat pretreated wastewater than raw wastewater in EWSs. This helps to avoid problems that may result from clogging and overloading of the systems.

For domestic wastewater sources, pre-treatment can be done in septic tanks, UASB reactors, and WSPs. For industrial wastewater rich in organics and nutrients, pre-treatment can essentially be the same as for domestic wastewater as well as in detention chambers that effect sedimentation in addition to acting as equalization basins. EWS area - to user population ratios (APRs) of $1-5 \mathrm{~m}^{2} / \mathrm{pe}$ can be used for sizing EWS. The full scale EWS cited in Table 3 operates satisfactorily at an APR of about $0.7 \mathrm{~m}^{2} / \mathrm{pe}$. Considering space constraints in many urban and peri-urban areas in Tanzania, it is impractical to employ WSP for pre-treatment of waste- 
Table 3. Performance Efficiency Profile for EWSs Treating Raw Industrial Wastewater and Septic Tank (ST) Effluent (Based on Mean Values) in Tanzania

\begin{tabular}{|c|c|c|c|c|}
\hline \multirow{2}{*}{ Parameter } & Influent Wastewater Type & Influent Concentration & $\begin{array}{c}\text { Performance Efficiency Range } \\
(\%)\end{array}$ & Relevant References \\
\hline \hline \multirow{2}{*}{$\mathrm{COD}(\mathrm{mg} / \mathrm{L})$} & Domestic ST effluent & $51-220$ & $70-88$ & {$[1,2]$} \\
\cline { 2 - 5 } & Raw textile effluent & $85-72$ & $46-86$ & {$[2,3]$} \\
\hline $\mathrm{BOD}(\mathrm{mg} / \mathrm{L})$ & Domestic ST effluent & $84-143$ & 58 & {$[2,3]$} \\
\hline $\mathrm{NH}_{4}{ }^{+}(\mathrm{mg} / \mathrm{L})$ & Domestic ST effluent & 35 & {$[2,3]$} \\
\hline $\mathrm{NO}_{3}{ }^{-}(\mathrm{mg} / \mathrm{L})$ & Domestic ST effluent & 0.91 & 55 & {$[2,3]$} \\
\hline \multirow{2}{*}{$\mathrm{SO}_{4}{ }^{2-}(\mathrm{mg} / \mathrm{L})$} & Domestic ST effluent & 46 & $53-59$ & {$[2,3]$} \\
\hline $\mathrm{Colour}$ & Raw textile effluent & 48 & $72-77$ & {$[2,3]$} \\
\hline $\mathrm{FC}\left(\mathrm{x} 10^{6}\right)$ & Raw textile effluent & Domestic ST effluent & $10-22$ & $66.1-99.99$ \\
\hline $\mathrm{TC}(\mathrm{x} \mathrm{10})$ & Domestic ST effluent & $25-59$ & $75-99.99$ & {$[1,2,3]$} \\
\hline
\end{tabular}

Table 4. Performance Efficiency Profile for EWSs Treating UASB Pre-Treated Effluent

\begin{tabular}{|c|c|c|c|c|}
\hline Parameter & Influent Wastewater Type & Influent Concentration & $\begin{array}{c}\text { Performance Efficiency } \\
\text { Range (\%) }\end{array}$ & Relevant References \\
\hline \hline $\mathrm{COD}(\mathrm{mg} / \mathrm{L})$ & UASB effluent & 117 & $75-80$ & {$[4-75$} \\
\hline $\mathrm{NH}_{4}{ }^{+}(\mathrm{mg} / \mathrm{L})$ & UASB effluent & 32 & $39-44$ & {$[6,12]$} \\
\hline $\mathrm{NO}_{3}{ }^{-}(\mathrm{mg} / \mathrm{L})$ & UASB effluent & 2.5 & $69-75$ & {$[6,12]$} \\
\hline $\mathrm{PO}_{4}{ }^{3-}(\mathrm{mg} / \mathrm{L})$ & UASB effluent & $6-19$ & $72-77$ & {$[6,12]$} \\
\hline $\mathrm{SO}_{4}{ }^{2-}(\mathrm{mg} / \mathrm{L})$ & UASB effluent & 40 & $62-67$ & {$[6,12]$} \\
\hline $\mathrm{FC}\left(\mathrm{x} 10^{6}\right)$ & UASB effluent & $11-17$ & $53-56$ & {$[6,11]$} \\
\hline $\mathrm{TC}\left(\mathrm{x} \mathrm{10} 0^{6}\right)$ & UASB effluent & $16-28$ & {$[6,11]$} \\
\hline
\end{tabular}

Units for faecal coliform (FC) and total coliform (TC), counts/100 mL.

water destined for an EWS. In terms of space, both the septic tank and UASB reactor compare favourably. However, in terms of treatment efficiency there are some differences. The UASB reactor is superior to the septic tank in terms of BOD and COD removal. Since the main purpose of anaerobic pretreatment is removal of organics, the UASB is preferable to the septic tank as a pre-treatment provision for both industrial and domestic wastewater. Equally important, the UASB not only treats wastewater more efficiently than the septic tank, but also produces biogas in the process, thereby effecting energy recovery. However, UASB reactors have more involving operation and maintenance needs, including the need for frequent removal and disposal of sludge, which may make their adoption at household level more challenging.

Storm water can be treated without pre-treatment in EWSs (especially FWS ones) or after passage through a sedimentation basin. Acid mine drainage can be treated in VUF raw or after preliminary treatment in a sedimentation basin. Treatment of acid mine drainage needs anaerobic conditions that enable the reduction of sulphate to hydrogen sulphide. For treatment of VOCs and other hazardous wastes as well as application in remediation of contaminated sites, options outlined earlier can be adopted, including the use of UVF EWS.

In all cases, attention should be paid to both the pretreatment and post - treatment needs of wastewater intended to be treated in EWSs. Also, it must be borne in mind that applicability of the technology is a function of the effluent quality desired. For example, if complete elimination of pathogens is required, post - treatment of EWS effluent through disinfection by UV radiation, chlorination or any other effective disinfection method, has to be employed. Other special purpose treatment needs that might employ EWSs need to be considered on case by case basis with reference to the relevant literature as cited in Table $\mathbf{2}$.

In addition to a remark made earlier, it is important to note that, the seemingly wide array of choices of EWS types has some applicability limitation if the best performance of the EWS is to be realised. For example, FWS EWS are said 
to be very poor in removing pathogens. Also, HF EWS are said to be poor at removing nutrients. Notably, the removal of nutrients (ammonia and nitrate - ammonia) can be achieved by employing a series of VDF (for nitrification) and HF SSF EWSs (for denitrification). For general treatment purposes, HF SSF and FWS EWSs are equally qualified. For removal of phosphorus, the wetland media type is very important. It is generally acknowledged that media that are rich in iron perform better those which are not.

It is further worth noting that FWS EWSs in warm malaria endemic areas like Dar es Salaam City, may not be suitable. In fact, since most parts of Tanzania are warm it is better to use SSF EWS to avoid problems of mosquito proliferation. Arguably, FWS EWSs can still be employed in Tanzania if their application is accompanied with effective malaria control strategies.

\subsection{Suitable Types of Wetland Plants}

On the whole, there are many types of wetland plants that may be used in EWS's. Globally, the following types of wetland plants are considered suitable for use in EWS's: reeds, cattails, taro, bulrush, rushes, sedges, and saw grass [1, 5, 26]. Considering treatment performance, experience acquired in Tanzania so far indicates that cattails, reeds, and taro are suitable for use as wetland plants. However, preference for one or another type of plant may as well base on aesthetic or other beneficial values of the plant of interest.

\subsection{Suitable Types of Wetland Media}

With respect to media, sand and aggregate (gravel) have been used successfully. Sand media produce a bacteriologically better effluent because of its higher straining effect. On the other hand, it can clog easily. Gravel does not clog easily, but it produces a comparatively poor effluent in bacteriological quality terms. A compromise between the two extremes is to use both types of media: gravel on the upstream side to handle suspended solids that can cause clogging easily, and sand on the downstream side to polish the effluent after removal of solids. In more specific terms, the inlet (distribution) zone (about $0.3-1.0 \mathrm{~m}$ long) of SSF EWS's can be filled with stones of sizes between $50 \mathrm{~mm}$ and $100 \mathrm{~mm}$. The outlet (collection) zone (about $0.3-1.0 \mathrm{~m}$ ) can be filled stones of sizes $38 \mathrm{~mm}-75 \mathrm{~mm}$. The media for the main EWS treatment area can constitute gravel of characteristic sizes between 10 and $25 \mathrm{~mm}$. The region of the EWS meant for polishing the effluent to remove pathogens can be filled with sand with a characteristic size of $2 \mathrm{~mm}$.

\subsection{Hydraulic and Pollutants Mass Loading Rates}

Depending on effluent quality desired and space availability as well as the wetland media used, the hydraulic retention time (HRT) based on empty bed retention time (EBRT) can be as short as one day or as long as 10 days. Based on experience acquired so far in Tanzania, applicable values of HRT range from 1.21 days to 5 days, but a value of 3 days would be considered safer $[12,13]$ though HLR values as high as $31 \mathrm{~cm} /$ day have been reported, it is probably safer to use values equal to or less than $14 \mathrm{~cm} /$ day. APR values range between $0.54 \mathrm{~m}^{2} \mathrm{pe}^{-1}$ and $5 \mathrm{~m}^{2} \mathrm{pe}^{-1}$, and a value close to $5 \mathrm{~m}^{2} \mathrm{pe}^{-1}$ would be considered reasonable.
Reported pollutants loading rates are in the ranges, 14-28 g COD m$~_{-2} \mathrm{~d}^{-1}$ for surface loading and 24-46 $\mathrm{g} \mathrm{COD} \mathrm{m}^{-3} \mathrm{~d}^{-1}$ for volumetric loading. The lower figures are considered to be more reasonable until more data that vindicate the higher values are available.

\section{CONCLUDING REMARKS}

Although there is an increasing body of knowledge on performance of EWSs in Tanzania, there are misconceptions, missing links, and gaps, and this paper sought to rectify the situation. It has been reiterated that engineered wetland systems (EWSs) are fashioned to mimic natural ecosystems for the purpose of treating wastewater and controlling pollution. It is noted that when employing EWSs it is important to bear in mind the natural origin of their mechanisms.

It has been pointed out that natural systems used for waste treatment and disposal can self-design themselves and depending on prevailing environmental conditions, especially hydrological ones, can transform themselves from one into another system. Examples of wetlands forming downstream of domestic wastewater outfalls and an island of wetland subsystem forming in the middle of a WSP where there is a formation of solids mound, have been given to support the notion of self - design of natural cum - engineered systems.

The main types of EWS have been identified as vertical flow (VF) and horizontal flow (HF) ones. The HF EWSs can either be subsurface flow (SSF) or free water surface (FWS). On the other hand, the VF can be vertical upflow (VUF) or vertical downflow (VDF) EWSs. Based on currently available literature from ARU and UDSM, EWS's treatment efficiencies for domestic effluent in Tanzania are $70-88 \%$ for COD removal, $40-86 \%$ for $\mathrm{BOD}_{5}, 46-75 \%$ for ammonia, 39$58 \%$ for nitrate, $69-75 \%$ for phosphorus, $55-77$ for sulphate, and $53-99.99 \%$ for both FC and TC.

EWSs can be applied to treat wastewater from a variety of sources in addition to domestic ones. These include industrial sources, mines and mineral processing sites, stormwater, agricultural establishments, recreational premises, and contaminated groundwater plumes. The type of EWS to be employed will depend on the wastewater to be treated. It has also been noted that, since most parts of Tanzania are warm it is better to use SSF EWS to avoid problems of mosquito proliferation.

\section{ACKNOWLEDGEMENTS}

Thanks are due to the Government of Sweden for providing research funding through the SIDA/Sarec Project of which Ardhi University is a beneficiary.

\section{REFERENCES}

[1] R. S. C. Reed, R. W. Crites and E.J. Middlebrooks, Natural Systems for Waste Management and Treatment, $2^{\text {nd }}$ ed. New York: McGraw-Hill, Inc., 1995.

[2] R. Crites and G. Tchobanoglous, Small and Decentralised Wastewater Management Systems, Boston: McGraw-Hill, 1998.

[3] R.H. Kadlec and R.L Knight, Treatment Wetlands. Boca Raton: CRC Press Lewis Publishers, 1996.

[4] S. Cole, "The Emergency of Treatment Wetlands", J. Environ. Sci. Tech., vol. 32, no. 9, pp. 218A - 223A, 1998. 
W. J. Mitsch and J. G. Gosselink, Wetlands, $3^{\text {rd }}$ ed. New York: John Wiley and Sons Inc., 2000.

[6] M.E. Kaseva, "Performance of Subsurface Horizontal Flow Constructed Wetland in Polishing Upflow Anaerobic Sludge Blanket Pre-treated Domestic Wastewater under Tropical Conditions-A Case Study in Dar es Salaam, Tanzania", presented at the Int. Conf. on Wetland Systems for Water Pollution Control, Grosvenor Resort, Lake Buena Vista, Florida, 2000.

[7] S. Zakayo, "Treatment of Wastewater in Engineered Wetlands", BSc. Dissertation, Dept. Env. Eng., University College of Lands and Architectural Studies, Dar es Salaam, Tanzania, 2000.

[8] E. Haule, "A Study for Optimisation of Performance of Constructed Wetlands in Treatment of Anaerobic Pre-treated Effluent". BSc. Dissertation, Dept. Env. Eng., University College of Lands and Architectural Studies, Dar es Salaam, Tanzania, 2001.

[9] J. Mgallah, "Application of Engineered Wetland Systems in the Treatment of Dye-rich Wastewater", BSc. Dissertation, Dept. Env. Eng., University College of Lands and Architectural Studies, Dar es Salaam, Tanzania, 2001.

[10] M.E. Kaseva, T.S. Mbwette, J. H. Katima, D.A. Mashauri, and S.E. Jorgensen, "Performance of Horizontal flow-subsurface Constructed Wetlands in the Removal of Total and Faecal Coliforms from Pre-treated Domestic Wastewater Effluent in Dar es Salaam, Tanzania", presented at the Int. Conf. on application of Wetland Systems and Waste Stabilization Ponds in Water Pollution Control, Dar es Salaam Tanzania, 2002.

[11] M.E. Kaseva, T.S. Mbwette, and J.H. Katima, "Domestic Sewage Treatment in a Pilot Plant Composed of Septic Tank and Constructed Wetlands-A Case Study in Dar es Salaam, Tanzania", presented at the IWA Conference on Wetland Systems for Water Pollution Control, Arusha, Tanzania, 2002.

[12] S. E. Mbuligwe, "Comparative Effectiveness of Engineered Wetland Systems (EWSs) in the treatment of anaeorobically pre-treated domestic wastewater". J. Ecol. Eng., vol. 23, no. 4-5, pp. 37-52, 2005.

[13] S. E. Mbuligwe, Applicability of a Septic Tank/Wetland coupled system in the treatment and recycling of wastewater from a small community. J. Environ. Manage., vol. 35, no. 1, pp. 99-108, 2005.

[14] S. E. Mbuligwe, Evolution and Role of Pseudo-natural Wetland Systems in Attenuation of Pollution: A Case Study of Dar es Salaam City presented at the Int. Conf. on Wetlands for Water Pollution Control, Grosvenor Resort, Lake Buena Vista, Florida, 2000.

[15] D. A. Mashauri, D.M. Mulungu and B.S. Abdulhussein, "Constructed Wetlands at the University of Dar es Salaam". J. Water Rese, vol. 34, no. 4, pp. 1135 -1144, 2002.

[16] A.T. Haule, H. B. Pratap, J. H. Katima, T. S. Mbwette and K. N. Njau, "Nitrogen Removal from Domestic Wastewater in Sub Surface Flow Constructed Wetland by Indigenous Macrophytes in the Tropics. A Comparative Study for Six Potential Macrophytes in Tanzania", presented at the Int. Conf. on Wetlands Systems for water Pollution Control, Arusha, Tanzania NZ 2000.

[17] M.A. Senzia, D. A. Mashauri, A.W. Mayo, T.S. Mbwette, J.H. Katima, H. B. Pratap and S.N. Nielsen. "Performance of Horizontal Subsurface Flow Constructed Wetlands Located downstream of Primary Facultative and Maturation Ponds in Tanzania", presented at the Int. Conf. on Wetlands Systems for water Pollution Control, Arusha, Tanzania, 2002

[18] S. E. Mbuligwe, Experience from the Community Infrastructure Upgrading Programme. J. Tanzania Eng., vol. 6, no. 6, pp. 21-29, 1997a.

[19] A. K. Kivaisi, The Potential of Constructed Wetlands for Wastewater Treatment and Reuse in Developing Countries. J. Ecol. Eng., vol. 16, pp. 545-560, 2001.

[20] D. A. Mashauri and S. Kayombo, Application of the two Coupled Models for Water Quality Management: Facultative Pond Cum Constructed Wetland Models. J. Phys. Chem. Earth Parts A B C vol. 27 no. (11/12), pp. 773-781, 2002.

[21] M.E. Kaseva, "Modelling of Constructed Wetlands for Polishing On-site Anaerobically pre-Treated Domestic Wastewater". PhD Thesis, University of Dar es Salaam, Dar es Salaam, Tanzania, 2000 .
[22] P. Denny, Wetlands Use and Conservation, in Wetlands of the World I: Inventory, Ecology and Management, vol. 15, no. 1, D. F. Whigham, D. Dykjovŭ and S. Hejnŷ, Eds. New York: Kluwer Publishers, 1993a, pp. $111-128$.

[23] P. Denny, Wetlands of Africa, in Wetlands of the World I: Inventory, Ecology and Management, vol. 15 no.1, D.F. Whigham, D. Dykjovŭ, and S. Hejnŷ, Eds. New York: Kluwer Publishers, 1993b, pp. 1- 31.

[24] P. Denny, Eastern Africa, in Wetlands of the World I: Inventory, Ecology and Management, vol. 15, no. 1, D.F. Whigham, D. Dykjovŭ, and S. Hejnŷ, Eds. New York: Kluwer Publishers, 1993c, pp. 32-46.

[25] G.R. Kassenga, A Descriptive Assessment of the Wetlands of the Lake Victoria Basin in Tanzania. J. Res. Conserv. Recycl. vol. 20, pp. 127-141, 1997.

[26] R.H. Kadlec, R.L. Knight, J. Vyamazal, H. Brix, P. Cooper and R. Haberl, "Constructed Wetlands for Water Pollution Control: Processes, Performance, Design and Operation". IWA Specialist Group on Use of Macrophytes in Water Pollution Control, Technical Report No. 8, IWA Publishing, 2000.

[27] Metcalf, and Eddy, "Wastewater Engineering: Treatment and Reuse", $3^{\text {rd }}$ ed." New Delhi: Tata McGraw-Hill Book Co, 1991.

[28] W. H. Patrick, "From Wastelands to Wetlands". J. Environ. Qual., vol. 23, pp. 892-896, 1994

[29] J. Williams, R. Ashworth, F. Martyn, E. May, R. Loveridge, M. Bahgat, and J. Butler, Physical and Chemical aspects of sewage treatment in Gravel Bed Hydroponic (GBH) systems. University of Portsmouth: Portsmouth, 1995.

[30] S. Camazine, J. Deneubourg, N. Franks, J. Sneyd, G. Thereulaz, and E. Bonbeau, Self Organization in Biological Systems. New Jersey: Princeton University Press, 2001.

[31] P. F. Cooper, G.D. Job, M.B. Green and R.B. Shutes, "Reed beds and Constructed Wetlands for Wastewater Treatment". Wiltshire, UK. WRc Swindon, 1996.

[32] P.A. Keddy and H.L. Fraser, "The Management of Wetlands for Biological Diversity: Four Principles" in Modern Trends in Applied Aquatic Ecology, R. S. Ambasht, and N. K. Ambasht, Eds. New York: Kluwer Academic/Plenum Publishers, 2003, pp. 21- 42.

[33] P. Cooper, "Constructed Wetlands and Reed Beds: Mature Technology for the Treatment of Wastewater from Small Populations". J. Chartered Inst.Water Environ. Manage, vol. 15, no. 2, pp. 79-85, 2001.

[34] P. F. Cooper, A. Thorton, G. Pearce, C, Abbott, N. Hasnip, "Constructed Wetlands to Remove Drainage Water: the Potential for Application of Constructed Wetlands in the Water Cycle in Developing Countries". WRC Report UC 3114, Department of International Development, Swindon, Wiltshire, United Kingdom, 1998.

[35] C. Campbell and M. Ogden, Constructed Wetlands in the Sustainable Landscape. New York: John Wiley \& Sons, Inc. 1999.

[36] R.K. Bastian and D. A Hammer, "The Use of Constructed Wetlands for Wastewater Treatment and Recycling", in Constructed Wetlands for Water Quality Improvement, G. A. Moshiri, Ed. Boca Raton: Lewis Publishers, pp. 59-68, 1993.

[37] S.S. Suthersan, Remediation Engineering: Design Concepts. Boca Raton: Lewis Publishers, 1999.

[38] R.C. Russel, Constructed Wetlands and Mosquitoes: Health Hazards and Management Options-An Australian Perspective. J. Ecol. Eng. vol. 12, pp. 107-124, 1999.

[39] G. R. Kassenga, J.H. Pardue and W.S Shin, Design Approaches for Chlorinated VOC Treatment Wetlands presented at the $2000 \mathrm{Int}$ Conf. on Wetlands and Remediation, Columbus, 2000.

[40] G. R. Kassenga, "Treatment of Chlorinated Volatile Organic Compounds in Wetlands". PhD Dissertation, Louisiana State University, Baton Rouge, USA, 2003.

[41] G. Mulamooth, E. A. McBean and F. Rovers, Constructed Wetlands for the Treatment of Landfill Leachates. Boca Raton: Lewis Publishers, 1999.

[42] M. D. La Grega, P. L. Buckingham, and J. C. Evans, Hazardous Waste Management. London: McGraw-Hill, 2001.

[43] T.H. Wiedemeier, H.S. Rifai, C.J. Newell, and J.T. Wilson, Natural Attenuation of Fuels and Chlorinated Solvents in the Subsurface. New York: John Wiley \& Sons, Inc., 1999. 
[44] Charbeneau, R. J., Groundwater Hydraulics and Contaminant Transport. Prentice Hall: Upper Saddle River, 2000.

[45] J.L. Schnoor, J.L., Environmental Modelling: Fate and Transport of Pollutants in Water, Air, and Soil. New York: John Wiley and Sons, 1996.
[46] G. R. Kassenga, J.H. Pardue, S. Blair, and T. Ferraro, "Treatment of Chlorinated Volatile Organic Compounds in Upflow Wetland Mesocosms". J. Ecol. Eng., vol. 19, pp. 305-323, 2003.

[47] P.F. Cooper, and B.C. Findlater, Constructed Wetlands in Water Pollution Control. Oxford: Pergamon Press, 1990.

(C) Mbuligwe et al.; Licensee Bentham Open.

This is an open access article licensed under the terms of the Creative Commons Attribution Non-Commercial License (http://creativecommons.org/licenses/by-nc/3.0/g) which permits unrestricted, non-commercial use, distribution and reproduction in any medium, provided the work is properly cited. 